\title{
Folate Intake, MTHFR Polymorphisms, and Risk of Esophageal, Gastric, and Pancreatic Cancer: A Meta-analysis
}

\section{Citation}

Larsson, Susanna C., Edward Giovannucci, and Alicja Wolk. 2006. "Folate Intake, MTHFR Polymorphisms, and Risk of Esophageal, Gastric, and Pancreatic Cancer: A Meta-Analysis." Gastroenterology 131 (4): 1271-83. https://doi.org/10.1053/j.gastro.2006.08.010.

\section{Permanent link}

http://nrs.harvard.edu/urn-3:HUL.InstRepos:41392097

\section{Terms of Use}

This article was downloaded from Harvard University's DASH repository, and is made available under the terms and conditions applicable to Other Posted Material, as set forth at http:// nrs.harvard.edu/urn-3:HUL.InstRepos:dash.current.terms-of-use\#LAA

\section{Share Your Story}

The Harvard community has made this article openly available. Please share how this access benefits you. Submit a story.

Accessibility 


\title{
SPECIAL REPORTS AND REVIEWS
}

\author{
Folate Intake, MTHFR Polymorphisms, and Risk of Esophageal, Gastric, and \\ Pancreatic Cancer: A Meta-analysis
}

\author{
SUSANNA C. LARSSON, ${ }^{*}$ EDWARD GIOVANNUCCI, ${ }^{\ddagger}$ and ALICJA WOLK* \\ *Division of Nutritional Epidemiology, National Institute of Environmental Medicine, Karolinska Institutet, Stockholm, Sweden; *Departments of Nutrition and \\ Epidemiology, Harvard School of Public Health, and Channing Laboratory, Department of Medicine, Brigham and Women's Hospital and Harvard Medical School, \\ Boston, Massachusetts
}

Background \& Aims: Increasing evidence suggests that a low folate intake and impaired folate metabolism may be implicated in the development of gastrointestinal cancers. We conducted a systematic review with meta-analysis of epidemiologic studies evaluating the association of folate intake or genetic polymorphisms in 5,10-methylenetetrahydrofolate reductase (MTHFR), a central enzyme in folate metabolism, with risk of esophageal, gastric, or pancreatic cancer. Methods: A literature search was performed using MEDLINE for studies published through March 2006. Study-specific relative risks were weighted by the inverse of their variance to obtain random-effects summary estimates. Results: The summary relative risks for the highest versus the lowest category of dietary folate intake were 0.66 (95\% confidence interval [CI], 0.53-0.83) for esophageal squamous cell carcinoma (4 case-control), 0.50 (95\% CI, 0.39-0.65) for esophageal adenocarcinoma (3 casecontrol), and 0.49 (95\% CI, $0.35-0.67)$ for pancreatic cancer (1 case-control, 4 cohort); there was no heterogeneity among studies. Results on dietary folate intake and risk of gastric cancer $(9$ case-control, 2 cohort) were inconsistent. In most studies, the MTHFR 677TT (variant) genotype, which is associated with reduced enzyme activity, was associated with an increased risk of esophageal squamous cell carcinoma, gastric cardia adenocarcinoma, noncardia gastric cancer, gastric cancer (all subsites), and pancreatic cancer; all but one of 22 odds ratios were $>1$, of which 13 estimates were statistically significant. Studies of the MTHFR A1298C polymorphism were limited and inconsistent. Conclusions: These findings support the hypothesis that folate may play a role in carcinogenesis of the esophagus, stomach, and pancreas.

$\mathrm{F}_{\mathrm{f} o \mathrm{sin}}$ olate is a water-soluble B vitamin found naturally in many foods, particularly in citrus fruits, green leafy vegetables, cruciferous vegetables, legumes, cereals, and liver. Evidence is mounting for a role of folate in carcinogenesis. There are 2 prominent mechanisms whereby folate deficiency may influence the risk of cancer: (1) by inducing misincorporation of uracil into DNA, which could lead to chromosomal breaks and mutations; and/or (2) by causing aberrant DNA methylation, resulting in altered expression of critical proto-oncogenes and tumor suppressor genes. ${ }^{1-3}$

Besides an inadequate folate intake, functional polymorphisms in folate-metabolizing genes may influence susceptibility to cancer. Among the several genetic polymorphisms in the folate metabolic pathway, polymorphisms in the 5,10-methylenetetrahydrofolate reductase (MTHFR) gene are the most extensively studied. MTHFR is a central enzyme in folate metabolism that irreversibly converts 5,10-methylenetetrahydrofolate to 5-methyltetrahydrofolate, the predominant form of folate in the circulation (Figure 1). Thus, MTHFR acts as a critical juncture in folate metabolism by directing folate metabolites toward the DNA methylation pathway and away from the DNA synthesis pathway. Two common functional polymorphisms of the MTHFR gene, C677T and A1298C, have been identified. ${ }^{4,5}$ Heterozygotes (CT) and homozygotes (TT) for the C677T polymorphism have about $65 \%$ and $30 \%$, respectively, of the MTHFR activity of individuals with the wild-type (CC) genotype. ${ }^{4}$ Individuals with the $T T$ genotype also have significantly lower plasma folate levels and higher plasma homocysteine levels than those with the CC genotype. ${ }^{6-8}$ For A1298C, homozygotes (CC) have about $60 \%$ of normal MTHFR activity. ${ }^{5}$ Studies on the effect of the A1298C polymorphism on folate and homocysteine levels are inconsistent. $5,6,9$

Other nutrients (eg, vitamin $\mathrm{B}_{6}$, vitamin $\mathrm{B}_{12}$, and methionine) involved in the folate metabolic pathway as well as alcohol (a folate antagonist) and smoking (which impairs folate status) may interact with folate and the MTHFR polymorphisms in relation to cancer risk. ${ }^{10,11}$ Vitamins $B_{6}$ and $B_{12}$ are coenzymes of serine hydroxymethyltransferase and methionine synthase, respectively, both of which are involved in folate metabolism (Figure 1). Alcohol may perturb folate metabolism by reducing folate absorption, ${ }^{12}$ by increasing folate excretion, ${ }^{12}$ or through inhibition of methionine synthase, ${ }^{13}$ which may trap folate as 5-methyltetrahydrofolate (Figure 1). The inverse association between folate intake and plasma homocysteine has been shown to be modified by alcohol intake and MTHFR 677 genotype but not by MTHFR 1298 genotype. ${ }^{14}$

Previous meta-analyses ${ }^{15,16}$ have shown inverse associations of dietary folate intake and the MTHFR 677TT genotype with risk of colorectal cancer. The aim of the present study was to assess the relationships of folate and the MTHFR C677T and A1298C polymorphisms with risk of esophageal, gastric, and pancreatic cancer by conducting meta-analyses of available case-

\footnotetext{
Abbreviations used in this paper: $\mathrm{Cl}$, confidence interval; MTHFR, methylenetetrahydrofolate reductase; $\mathrm{OR}$, odds ratio; $\mathrm{RR}$, relative risk.

(C) 2006 by the American Gastroenterological Association (AGA) Institute $0016-5085 / 06 / \$ 32.00$ doi:10.1053/j.gastro.2006.08.010
} 


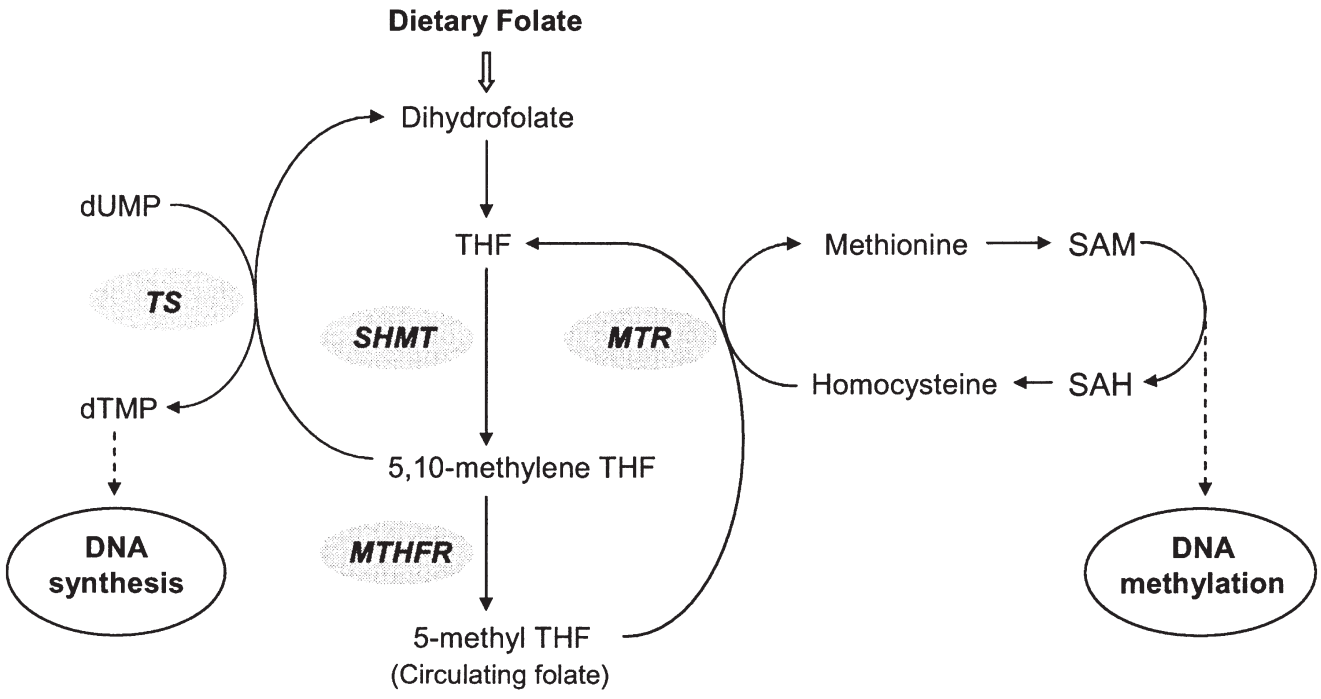

Figure 1. Simplified overview of folate metabolism involving DNA synthesis and DNA methylation. Enzymes: TS, thymidylate synthase; SHMT, serine hydroxymethyltransferase; MTHFR, 5,10-methylenetetrahydrofolate reductase; MTR, methionine synthase. Metabolites: THF, tetrahydrofolate; dTMP, deoxythymidine monophosphate; dUMP, deoxyuridine monophosphate; SAH, S-adenosylhomocysteine; SAM, S-adenosylmethionine. control and cohort studies. We also examined whether the associations of folate and the MTHFR polymorphisms with cancer risk were modified by vitamins $\mathrm{B}_{6}$ and $\mathrm{B}_{12}$, methionine, alcohol, and smoking.

\section{Materials and Methods}

\section{Study Selection}

A computerized literature search was conducted in MEDLINE for studies published in any language from 1966 to March 2006 using the key words folate, folic acid, or MTHFR in combination with cancer, neoplasm, or the individual cancer sites. We also reviewed the reference lists of the relevant articles to identify additional studies. Because folate intake frequently was only one of several dietary factors studied, reports that had fruit, vegetables, vitamins, or nutrients as key words were scrutinized for findings on folate.

Studies were included if they (1) presented original data from case-control or cohort studies and (2) provided odds ratios (ORs) or rate ratios with their confidence intervals (CIs) for the association of dietary folate intake (ie, folate from foods), total folate intake (ie, folate from foods and dietary supplements), blood folate levels, or polymorphisms in the MTHFR gene with esophageal, gastric, or pancreatic cancer risk. Studies were excluded if they provided only a risk estimate with no means by which to calculate the CI or if the risk estimate was not adjusted by age. When there were multiple publications from the same population, only the most recently published report was included.

\section{Data Extraction}

We extracted the following data from each publication: the first author's last name, year of publication, country where the study was performed, study design, type of controls in case-control studies, sample size, measure of exposure, outcome, prevalence of the variant genotype in the study population, covariates adjusted for by matching or in the analysis, and the risk estimates with $95 \%$ CIs for the highest versus the lowest intake categories of folate or for the MTHFR variant genotypes.
From each study, we extracted the risk estimates that reflected the greatest degree of control for potential confounders.

\section{Statistical Analysis}

We weighted the study-specific log ORs for case-control studies and log rate ratios for cohort studies by the inverse of the variance to compute summary relative risk (RR) estimates with 95\% CIs. Because the absolute risk of the cancers considered in this meta-analysis is low, ORs in case-control studies and rate ratios in cohort studies yield similar estimates of RR. ${ }^{17}$ Studies were pooled with the DerSimonian and Laird randomeffects model, which considers both within- and between-study variability. ${ }^{18}$ When separate RRs were provided for the intestinal and diffuse types of gastric cancer, ${ }^{19}$ for cardia and noncardia gastric cancer, ${ }^{20}$ or for men and women, ${ }^{21}$ we pooled the RRs (weighted by the inverse of their variance) to obtain one RR from each study.

Statistical heterogeneity among studies was assessed with the $\mathrm{Q}$ and $\mathrm{I}^{2}$ statistics. $^{22}$ For the $\mathrm{Q}$ statistic, heterogeneity was considered present if $P<.1$. $\mathrm{I}^{2}$ is the proportion of total variation contributed by between-study variability. ${ }^{22}$ We used random-effects meta-regression to investigate sources of heterogeneity and to provide an estimate of unexplained heterogeneity, $\tau^{2}{ }^{23,24}$ Study characteristics examined included study design (case-control vs cohort), type of controls in case-control studies (population-based vs hospital-based), and geographical area (United States, Europe, other). We used funnel plots and Egger's regression asymmetry test to evaluate publication bias $^{25}(P<.1$ was considered representative of statistically significant publication bias). The potential influence that unpublished studies could have on the summary estimate was examined using trim and fill analysis. ${ }^{26}$ All analyses were performed with Stata statistical software (version 9.0; StataCorp, College Station, TX).

\section{Results}

\section{Folate Intake}

Esophageal cancer. We identified 11 case-control studies $^{20,27-36}$ that evaluated the association between dietary 
folate intake and risk of esophageal cancer. Four studies were excluded for the following reasons: no CIs, ${ }^{33,34}$ duplicate publications, ${ }^{35}$ or the RR was not adjusted by age. ${ }^{36}$ The 7 remaining studies ${ }^{20,27-32}$ were included in the meta-analysis (Table 1). All studies adjusted for potential confounding by smoking and alcohol intake, and 5 studies also controlled for body mass index. The summary RRs for individuals in the highest relative to the lowest category of dietary folate intake were 0.66 (95\% CI, 0.53-0.83) for esophageal squamous cell carcinoma (total of 929 cases) and 0.50 (95\% CI, 0.39-0.65) for esophageal adenocarcinoma (total of 501 cases) (Figure 2). When all 7 studies (including 1496 cases) were analyzed together, the summary RR of esophageal cancer (all types) was 0.62 (95\% CI, 0.53-0.72) for high versus low dietary folate intake. There was no heterogeneity among these studies $\left(\mathrm{Q}=5.27 ; P=.51 ; \mathrm{I}^{2}=0 \%\right)$. The association was similar in population-based case-control studies (RR, 0.52; 95\% CI, 0.42-0.65) and hospital-based case-control studies (RR, 0.74; 95\% CI, 0.59-0.92). The Egger's test provided no indication of publication bias $(P=.33$ for all studies, $P=.36$ for esophageal squamous cell carcinoma, and $P$ $=.33$ for esophageal adenocarcinoma).

Gastric cancer. We identified 11 case-control ${ }^{19-21,31,37-43}$ and 2 cohort studies ${ }^{44,45}$ that examined the association between dietary folate intake and risk of gastric cancer. Two case-control studies were excluded for the following reasons: no $\mathrm{CI}^{37}$ or duplicate publications. ${ }^{39}$ Eleven studies with 3205 cases met the predefined inclusion criteria (Table 1). Among these studies, 9 reported results on cardia and noncardia gastric cancers combined, ${ }^{19,21,38,40-45}$ one presented results on both cancer sites, ${ }^{20}$ and one included noncardia gastric cancer cases only. ${ }^{31}$ In the study ${ }^{20}$ that provided results for the 2 subsites, high versus low dietary folate intake was associated with a statistically significant lower risk of both gastric cardia adenocarcinoma (RR, 0.73; 95\% CI, 0.55-0.97) and noncardia gastric cancer (RR, 0.67; 95\% CI, 0.51-0.88). Overall, there was no significant association between dietary folate intake and risk of gastric cancer; however, there was significant heterogeneity among all studies and among the case-control studies but not among the cohort studies (Figure 3). In meta-regression analysis, geographical region but not study design was a predictor of between-study heterogeneity. The between-study variance $\left(\tau^{2}\right)$ was reduced from 0.070 to 0.000 when including geographical region in the meta-regression model. The summary RRs for individuals in the highest relative to the lowest category of dietary folate intake were 0.68 (95\% CI, $0.58-0.80)$ for studies conducted in the United States ( $\mathrm{n}=4), 1.15$ (95\% CI, 0.91-1.45) for European studies $(\mathrm{n}=4)$, and 0.89 (95\% CI, $0.40-1.96)$ for studies $(\mathrm{n}=$ 3 ) conducted elsewhere. There was no heterogeneity among the US studies $\left(\mathrm{Q}=1.06 ; P=.79 ; \mathrm{I}^{2}=0 \%\right)$ or among the European studies $\left(\mathrm{Q}=1.04 ; P=.79 ; \mathrm{I}^{2}=0 \%\right)$. The Egger's test for publication bias was not statistically significant $(P=.28)$.

Pancreatic cancer. The association between dietary folate intake and pancreatic cancer risk was examined in 2 case-control ${ }^{46,47}$ and 4 cohort studies $^{48-50}$ (one study ${ }^{49}$ reported data from 2 independent cohorts, which were included in the meta-analysis as 2 separate studies). One case-control study ${ }^{46}$ was excluded because no CI was provided. All 5 analyzed studies (involving 722 cases) reported an inverse association between dietary folate intake and pancreatic cancer risk, and in 3 studies $47,48,50$ the relationship was statistically significant (Table 1). The summary estimate indicates that individuals in the highest category of dietary folate intake have a significant 51\% lower risk of pancreatic cancer compared with those in the lowest category; there was no heterogeneity among studies (Figure 4). Restricting the analysis to cohort studies yielded similar results (RR, 0.52; 95\% CI, 0.36-0.75). There was no strong evidence of publication bias ( $P=.28$ by Egger's test). Three cohort studies provided results on total folate intake and risk of pancreatic cancer, with a significant inverse association observed in one study $(\mathrm{RR}, 0.33 ; 95 \% \mathrm{CI}, 0.15-0.72)^{50}$ but not in the 2 other studies. ${ }^{49}$

\section{Blood Folate Levels}

In a case-control study in China, significantly $(P<$ .0001) lower serum folate levels were found among cases with esophageal squamous cell carcinoma and gastric cardia carcinoma compared with healthy controls. ${ }^{51}$ The ORs (adjusted for age, sex, and smoking) of squamous cell carcinoma and gastric cardia carcinoma were 13.73 (95\% CI, 9.61-19.60) and $2.43(95 \%$ CI, 1.64-3.60), respectively, for low $(<3 \mathrm{ng} / \mathrm{mL})$ versus high $(\geq 3 \mathrm{ng} / \mathrm{mL})$ serum folate status. ${ }^{51}$

In a nested case-control study within the Alpha-Tocopherol, Beta-Carotene Cancer Prevention Study cohort of male Finnish smokers, serum folate levels were significantly $(P=.009)$ inversely associated with risk for pancreatic cancer. ${ }^{52}$ Men in the highest tertile of serum folate levels had approximately half the risk of pancreatic cancer (RR, 0.45 ; 95\% CI, 0.24-0.82) compared with men in the lowest tertile. ${ }^{52}$

\section{Folate/Other Nutrients and Smoking Interactions}

Galeone et $\mathrm{al}^{29}$ reported that the inverse association of folate intake with risk of esophageal squamous cell carcinoma was stronger among individuals with high vitamin $\mathrm{B}_{6}$ and methionine intake (above the median values). Two prospective studies showed no interaction between folate and methionine intake in relation to risk of gastric cancer ${ }^{45}$ or pancreatic cancer. ${ }^{49}$

In an Italian case-control study, the inverse association between folate intake and risk of esophageal squamous cell carcinoma was stronger among heavy drinkers (RR for an increment in folate intake of $98 \mu \mathrm{g} / \mathrm{day}, 0.74)$ than among moderate drinkers (corresponding RR, 0.96). ${ }^{29}$ Neither alcohol nor smoking was found to significantly modify the inverse relation between folate intake and pancreatic cancer in 3 prospective studies. ${ }^{48-50}$

\section{MTHFR Polymorphisms}

MTHFR C677T. We identified 18 publications $^{28,53-69}$ with data on the MTHFR C677T polymorphism in relation to esophageal squamous cell carcinoma, gastric cardia adenocarcinoma, noncardia gastric cancer, gastric cancer (all sites), or pancreatic cancer (some publications provided data on more than one outcome $54,57,60,61$ or by ethnicity ${ }^{56}$ ) (Table 2). Two studies were excluded because of duplicate publications. ${ }^{58,62}$ Among the 16 included studies, 10 were conducted in a Chinese population. ${ }^{53-57,59,60,63,64,68}$ The prevalence of the TT genotype among controls varied considerably among studies, ranging from $6.5 \%$ (in US white patients) ${ }^{67}$ to $44.0 \%$ (in a Chinese population). ${ }^{56}$ The MTHFR C677T genotype frequency in controls was in Hardy-Weinberg equilibrium in all but one study. ${ }^{60}$ Figure 5 shows the OR for the TT genotype compared with the 
Table 1. Studies of Dietary Folate Intake and Risk of Esophageal, Gastric, and Pancreatic Cancer

\begin{tabular}{|c|c|c|c|c|c|c|c|}
\hline Reference & $\begin{array}{l}\text { Country, study } \\
\text { design }\end{array}$ & $\begin{array}{l}\text { Years of } \\
\text { study }\end{array}$ & Cases & Controls $^{a}$ & $\begin{array}{l}\text { Range of intake } \\
(\mu \mathrm{g} / \text { day })\end{array}$ & $\begin{array}{l}\text { Adjusted RR } \\
(95 \% \mathrm{CI})^{b}\end{array}$ & Adjustments \\
\hline \multicolumn{8}{|c|}{ Esophageal squamous cell carcinoma } \\
\hline Brown et al, $1988^{27}$ & $\begin{array}{l}\text { United States, } \\
\text { case-control }\end{array}$ & 1982-1984 & $207^{c}$ & $422(\mathrm{H})$ & $\begin{array}{l}\text { Highest vs lowest } \\
\text { tertile }^{d}\end{array}$ & $0.7(0.4-1.3)$ & $\begin{array}{l}\text { Age, race, hospital, } \\
\text { country of residence, } \\
\text { smoking, moonshine } \\
\text { use, and alcohol intake }\end{array}$ \\
\hline Mayne et al, $2001^{20}$ & $\begin{array}{l}\text { United States, } \\
\text { case-control }\end{array}$ & 1993-1995 & 206 & $687(P)$ & $\begin{array}{l}\text { Highest vs lowest } \\
\text { quartile }^{d}\end{array}$ & $0.58(0.39-0.86)$ & $\begin{array}{l}\text { Age, sex, race, education, } \\
\text { proxy status, income, } \\
\text { smoking, BMl, beer, } \\
\text { wine, liquor, and } \\
\text { energy intake }\end{array}$ \\
\hline Yang et al, $2005^{28}$ & $\begin{array}{l}\text { Japan, } \\
\text { case-control }\end{array}$ & 2001-2004 & $165^{e}$ & $495(H)$ & $>400$ vs $<300$ & $0.77(0.45-1.31)$ & $\begin{array}{l}\text { Age, sex, smoking, and } \\
\text { alcohol intake }\end{array}$ \\
\hline Galeone et al, $2006^{29}$ & $\begin{array}{l}\text { Italy and } \\
\text { Switzerland, } \\
\text { case-control }\end{array}$ & 1992-1999 & 351 & $875(\mathrm{H})$ & $>305$ vs $<228$ & $0.68(0.46-1.00)$ & $\begin{array}{l}\text { Age, center, education, } \\
\text { smoking, BMI, and } \\
\text { alcohol intake }\end{array}$ \\
\hline \multicolumn{8}{|l|}{ Esophageal adeonocarcinoma } \\
\hline Zhang et al, $1997^{30}$ & $\begin{array}{l}\text { United States, } \\
\text { case-control }\end{array}$ & 1992-1994 & $95^{f}$ & $132(H)$ & $\begin{array}{l}\text { Highest vs lowest } \\
\text { quartile }^{d}\end{array}$ & $0.7(0.3-1.8)$ & $\begin{array}{l}\text { Age, sex, race, education, } \\
\text { smoking, BMI, and } \\
\text { intake of alcohol and } \\
\text { energy }\end{array}$ \\
\hline Mayne et al, $2001^{20}$ & $\begin{array}{l}\text { United States, } \\
\text { case-control }\end{array}$ & 1993-1995 & 282 & $687(P)$ & $\begin{array}{l}\text { Highest vs lowest } \\
\text { quartile }^{d}\end{array}$ & $0.48(0.36-0.66)$ & $\begin{array}{l}\text { Age, sex, race, education, } \\
\text { proxy status, income, } \\
\text { smoking, BMI, and } \\
\text { intake of beer, wine, } \\
\text { liquor, and energy }\end{array}$ \\
\hline Chen et al, $2002^{31}$ & $\begin{array}{l}\text { United States, } \\
\text { case-control }\end{array}$ & 1988-1994 & 124 & $449(\mathrm{P})$ & $\begin{array}{l}\text { Highest vs lowest } \\
\text { quartile }^{d}\end{array}$ & $0.5(0.3-1.0)$ & $\begin{array}{l}\text { Age, sex, education, } \\
\text { respondent type, } \\
\text { smoking, family history, } \\
\text { vitamin, BMI, } \\
\text { supplement use, and } \\
\text { alcohol intake }\end{array}$ \\
\hline \multicolumn{8}{|c|}{ Esophageal carcinoma (all types) } \\
\hline De Stefani et al, $1999^{32}$ & $\begin{array}{l}\text { Uruguay, } \\
\text { case-control }\end{array}$ & 1996-1997 & 66 & $393(H)$ & $\begin{array}{l}\text { Highest vs lowest } \\
\text { tertile }^{d}\end{array}$ & $0.8(0.5-1.1)$ & $\begin{array}{l}\text { Age, sex, education, } \\
\text { place of residence, } \\
\text { urban/rural, smoking, } \\
\text { BMI, and intake of } \\
\text { alcohol and energy }\end{array}$ \\
\hline \multicolumn{8}{|l|}{ Gastric cancer } \\
\hline La Vecchia et al, $1994^{38}$ & $\begin{array}{l}\text { Italy, } \\
\quad \text { case-control }\end{array}$ & 1985-1992 & 723 & $2024(H)$ & $>262$ vs $<163$ & $1.33(0.82-2.18)$ & $\begin{array}{l}\text { Age, sex, education, } \\
\text { family history, BMI, and } \\
\text { intake of nitrites, } \\
\text { nitrates, methionine, } \\
\beta \text {-carotene, vitamin C, } \\
\text { and energy }\end{array}$ \\
\hline Harrison et al, $1997^{19}$ & $\begin{array}{l}\text { United States, } \\
\text { case-control }\end{array}$ & 1992-1994 & 91 & $132(\mathrm{H})$ & High vs lowe & $0.60(0.44-0.82)$ & $\begin{array}{l}\text { Age, sex, race, education, } \\
\text { smoking, BMI, and } \\
\text { alcohol intake }\end{array}$ \\
\hline López-Carrillo et al, 199940 & $\begin{array}{l}\text { Mexico, } \\
\text { case-control }\end{array}$ & 1989-1990 & 220 & $752(P)$ & $\geq 466$ vs $<257$ & $1.00(0.45-2.27)$ & $\begin{array}{l}\text { Age, sex, SES, history of } \\
\text { peptic ulcer, smoking, } \\
\text { and intake of salt, chili- } \\
\text { pepper, and energy }\end{array}$ \\
\hline Botterweck et al, $2000^{44}$ & $\begin{array}{l}\text { The Netherlands, } \\
\text { cohort (NCS) }\end{array}$ & 1986-1992 & 282 & 3123 & $\begin{array}{c}384 \text { vs } 202 \\
\text { (median) }\end{array}$ & $1.00(0.60-1.40)$ & $\begin{array}{l}\text { Age, sex, education, } \\
\text { smoking, stomach } \\
\text { disorders, and family } \\
\text { history }\end{array}$ \\
\hline Muñoz et al, $2001^{41}$ & $\begin{array}{l}\text { Venezuela, } \\
\text { case-control }\end{array}$ & 1991-1996 & 292 & $485(\mathrm{P})$ & $\begin{array}{l}\text { Highest vs lowest } \\
\text { quartile }\end{array}$ & $1.51(0.93-2.45)$ & $\begin{array}{l}\text { Age, sex, SES, tobacco, } \\
\text { and intake of alcohol } \\
\text { and energy }\end{array}$ \\
\hline Mayne et al, $2001^{20}$ & $\begin{array}{l}\text { United States, } \\
\text { case-control }\end{array}$ & 1993-1995 & 607 & $687(\mathrm{P})$ & $\begin{array}{l}\text { Highest vs lowest } \\
\text { quartile }\end{array}$ & $0.70(0.57-0.85)$ & $\begin{array}{l}\text { Age, sex, race, education, } \\
\text { proxy status, income, } \\
\text { smoking, BMI, and } \\
\text { intake of beer, wine, } \\
\text { liquor, and energy }\end{array}$ \\
\hline Chen et al, $2002^{31}$ & $\begin{array}{l}\text { United States, } \\
\text { case-control }\end{array}$ & 1988-1994 & $124 g$ & $449(\mathrm{P})$ & $\begin{array}{l}\text { Highest vs lowest } \\
\text { quartile }\end{array}$ & $0.80(0.40-1.40)$ & $\begin{array}{l}\text { Age, sex, respondent } \\
\text { type, tobacco, } \\
\text { education, family } \\
\text { history, vitamin } \\
\text { supplement use, and } \\
\text { alcohol intake }\end{array}$ \\
\hline Nomura et al, $2003^{21}$ & $\begin{array}{l}\text { United States } \\
\text { (Hawaii), } \\
\text { case-control }\end{array}$ & 1993-1999 & 300 & $446(P)$ & $>315$ vs $<236$ & $0.76(0.38-1.51)$ & $\begin{array}{l}\text { Age, ethnicity, education, } \\
\text { smoking, history of } \\
\text { gastric ulcer, family } \\
\text { history, NSAID use, } \\
\text { and intake of fiber, } \beta \text { - } \\
\text { carotene, vitamin C, } \\
\text { vitamin E, and energy }\end{array}$ \\
\hline
\end{tabular}


Table 1 (continued). Studies of Dietary Folate Intake and Risk of Esophageal, Gastric, and Pancreatic Cancer

\begin{tabular}{|c|c|c|c|c|c|c|c|}
\hline Reference & $\begin{array}{l}\text { Country, study } \\
\text { design }\end{array}$ & $\begin{array}{l}\text { Years of } \\
\text { study }\end{array}$ & Cases & Controls $^{a}$ & $\begin{array}{l}\text { Range of intake } \\
(\mu \mathrm{g} / \text { day })\end{array}$ & $\begin{array}{l}\text { Adjusted RR } \\
(95 \% \mathrm{CI})^{b}\end{array}$ & Adjustments \\
\hline Lissowska et al, $2004^{42}$ & $\begin{array}{l}\text { Poland, } \\
\text { case-control }\end{array}$ & 1994-1996 & 274 & $463(\mathrm{P})$ & $\begin{array}{l}\text { Highest vs lowest } \\
\text { quartile }\end{array}$ & $1.26(0.81-1.98)$ & $\begin{array}{l}\text { Age, sex, education, } \\
\text { smoking, and energy } \\
\text { intake }\end{array}$ \\
\hline Kim et al, $2005^{43}$ & $\begin{array}{l}\text { Korea, } \\
\quad \text { case-control }\end{array}$ & 1997-1998 & 136 & $136(\mathrm{H})$ & $\geq 354$ vs $<234$ & $0.35(0.13-0.96)$ & $\begin{array}{l}\text { Age, sex, SES, family } \\
\text { history, refrigerator } \\
\text { use, and } H \text { pylori } \\
\text { infection }\end{array}$ \\
\hline Larsson et al, $2006^{45}$ & $\begin{array}{l}\text { Sweden, } \\
\text { cohort (SMC) }\end{array}$ & 1987-2004 & 156 & 61,433 & $\geq 260$ vs $<203$ & $1.04(0.61-1.86)$ & $\begin{array}{l}\text { Age, education, and } \\
\text { intake of alcohol, } \\
\text { coffee, tea, } \beta \text {-carotene, } \\
\text { vitamin } C \text {, and energy }\end{array}$ \\
\hline \multicolumn{8}{|l|}{ Pancreatic cancer } \\
\hline Baghurst et al, $1991^{47}$ & $\begin{array}{l}\text { Australia, } \\
\text { case-control }\end{array}$ & 1984-1987 & 104 & $253(P)$ & $\begin{array}{l}\text { Highest vs lowest } \\
\text { quartile }\end{array}$ & $0.36(0.18-0.74)$ & $\begin{array}{l}\text { Age, sex, smoking, and } \\
\text { intake of alcohol and } \\
\text { energy }\end{array}$ \\
\hline $\begin{array}{l}\text { Stolzenberg Solomon et al, } \\
2001^{48}\end{array}$ & $\begin{array}{l}\text { Finland, } \\
\text { cohort (ATBC) }\end{array}$ & 1985-1997 & 157 & 29.133 & $>373$ vs $\leq 280$ & $0.52(0.31-0.87)$ & Age, intervention group \\
\hline Skinner et al, $2004^{49}$ & $\begin{array}{l}\text { United States, } \\
\text { cohort (HPFS) }\end{array}$ & 1986-2000 & 187 & 47,840 & $\geq 500$ vs $<300$ & $0.66(0.37-1.18)$ & $\begin{array}{l}\text { Age, time period, } \\
\text { smoking, height, BMI, } \\
\text { diabetes, and energy } \\
\text { intake }\end{array}$ \\
\hline Skinner et al, $2004^{49}$ & $\begin{array}{l}\text { United States, } \\
\text { cohort (NHS) }\end{array}$ & 1984-1998 & 139 & 77,640 & $\geq 400$ vs $<200$ & $0.65(0.31-1.35)$ & $\begin{array}{l}\text { Age, time period, } \\
\text { smoking, height, BMI, } \\
\text { diabetes, and energy } \\
\text { intake }\end{array}$ \\
\hline Larsson et al, $2006^{50}$ & $\begin{array}{l}\text { Sweden, } \\
\text { cohort (SMC, } \\
\text { cosM) }\end{array}$ & 1998-2004 & 135 & 81,922 & $\geq 350$ vs $<200$ & $0.25(0.11-0.59)$ & $\begin{array}{l}\text { Age, sex, education, } \\
\text { smoking, BMI, } \\
\text { exercise, diabetes, and } \\
\text { intake of fruits, } \\
\text { vegetables, } \\
\text { carbohydrates, and } \\
\text { energy }\end{array}$ \\
\hline
\end{tabular}

ATBC, Alpha-Tocopherol, Beta-Carotene Cancer Prevention Study; BMI, body mass index; COSM; Cohort of Swedish Men; HPFS, Health Professionals Follow-up Study; NCS, Netherlands Cohort Study; NHS, Nurses' Health Study; NSAID, nonsteroidal anti-inflammatory drugs; SES, socioeconomic status; SMC, Swedish Mammography Cohort.

aType of controls in parentheses $(\mathrm{H}$, hospital-based; $\mathrm{P}$, population-based).

${ }^{b}$ Relative risk for the highest vs the lowest intake category; the measure of RR is an OR in case-control studies.

${ }^{c}$ The histologic types of esophageal cancer were squamous cell carcinoma (85\%), adenocarcinoma (13\%), and carcinosarcoma (2\%).

The range of intake was not reported.

elncluding 6 cases with esophageal adenocarcinoma.

${ }^{f}$ Adenocarcinoma of the esophagus and gastric cardia.

gNoncardia gastric cancer.

CC genotype in individual studies, stratified by cancer site. All but one of the 22 ORs were $>1$, suggesting that the TT genotype is associated with an increased cancer risk; 13 estimates were statistically significant. Overall, compared with individuals with the CC genotype, individuals with the TT genotype had a significantly higher odds of gastric cardia adenocarcinoma (OR, 1.90; 95\% CI, 1.38-2.60) and gastric cancer (OR, 1.68; 95\% CI, 1.29-2.19). There was no significant heterogeneity among the studies of gastric cardia adenocarcinoma $\left(\mathrm{Q}=4.94 ; P=.29 ; \mathrm{I}^{2}\right.$ $=19 \%)$ or among the studies of gastric cancer $(\mathrm{Q}=8.86 ; P=$ $\left..12 ; \mathrm{I}^{2}=43.6 \%\right)$. However, substantial heterogeneity was present among the studies of esophageal squamous cell carcinoma (Q $\left.=29.01 ; P<.001 ; \mathrm{I}^{2}=79.3 \%\right)$ and among the studies of pancreatic cancer $\left(\mathrm{Q}=15.97 ; P<.001 ; I^{2}=87.5 \%\right)$, which precluded calculation of a summary estimate. For esophageal squamous cell carcinoma, heterogeneity remained after excluding the only hospital-based case-control study ${ }^{28}$ and when the analysis was restricted to the 5 studies conducted in a Chinese population. ${ }^{53-57}$ There was no indication of publication bias in the literature on esophageal cancer $(P=.80)$, gastric cardia adenocarcinoma $(P=.51)$, or pancreatic cancer $(P=.65)$. For gastric cancer, the funnel plot suggested a relative absence of small studies showing no association with the TT genotype $(P=$
.003 by Egger's test). According to the trim and fill analysis, 2 such studies may be missing. Adding those missing studies to the meta-analysis yielded a summary OR of gastric cancer of 1.48 (95\% CI, 1.14-1.94) for TT versus CC genotype.

MTHFR A1298C. We identified 10 studies ${ }^{53,54,58-60,65,67-70}$ on the MTHFR A1298C polymorphism (Table 3). One study 58 was excluded because it was superseded by a later report. ${ }^{60}$ The prevalence of the CC genotype among controls ranged from $0 \%$ (in Chinese populations) ${ }^{54,70}$ to $12.9 \%$ (in US white patients). ${ }^{67}$ The MTHFR A1298C genotype frequency in controls was in Hardy-Weinberg equilibrium in all studies. In 2 studies, individuals with the $C C$ genotype, compared with those with the $A A$ genotype, had a significantly higher odds of esophageal squamous cell carcinoma ${ }^{53}$ or pancreatic cancer. ${ }^{69}$ The other studies either did not observe any significant associations ${ }^{59,60,65,67,68}$ or had no cases or controls with the CC genotype. ${ }^{54,70}$

\section{Gene/Environment Interactions}

MTHFR C677T. Seven of 9 studies suggest interactions between alcohol intake or smoking and C677T in relation to cancer risk (Table 2). Stolzenberg-Solomon et $\mathrm{al}^{54}$ reported a significant interaction $(P=.03)$ between C677T and alcohol intake in relation to risk of gastric cardia adenocarcinoma; in 


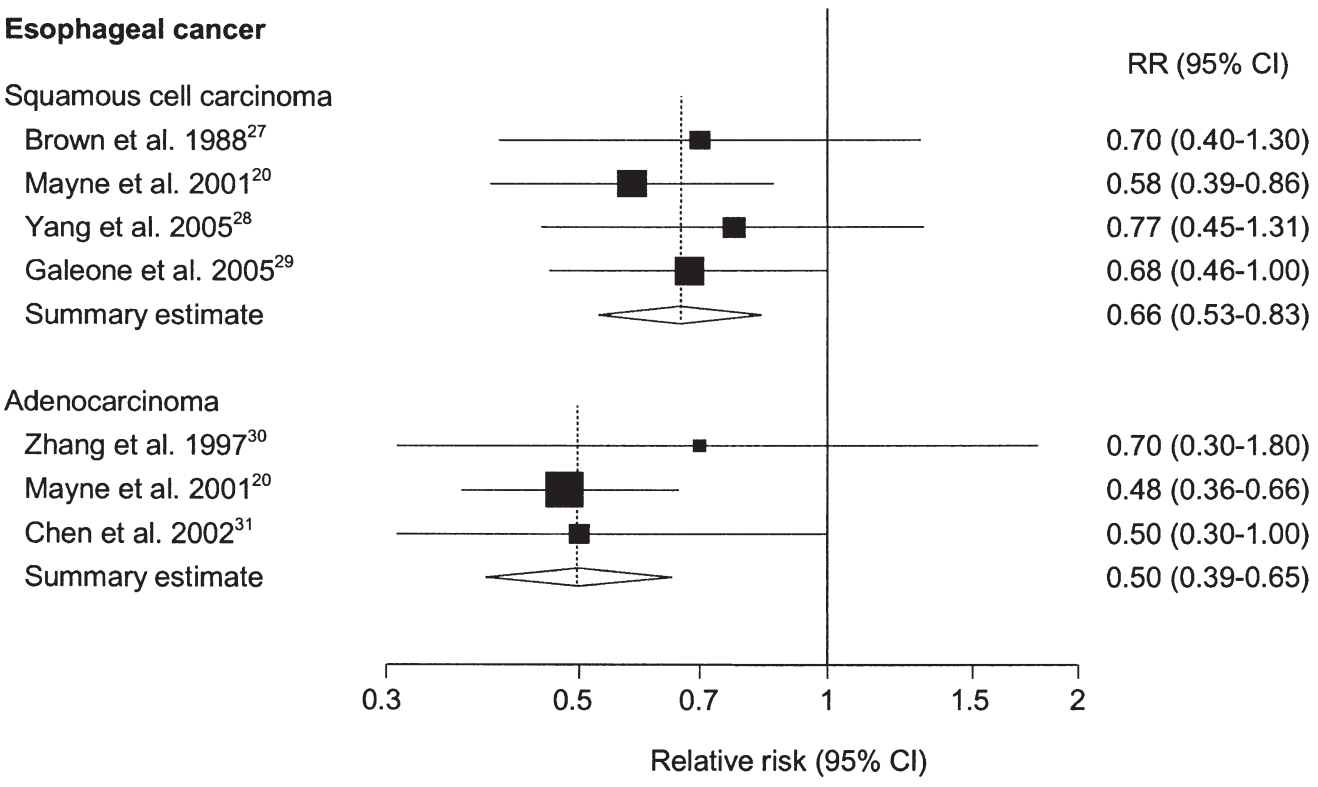

Figure 2. RRs and $95 \% \mathrm{Cls}$ of esophageal squamous cell carcinoma and esophageal adenocarcinoma for highest versus lowest dietary folate intake category in individual case-control studies and for all studies combined. The size of the data markers (squares) represents the statistical weight that each study contributed to the random-effects summary estimates; horizontal lines represent the 95\% Cls. The summary RRs for each histologic subtype and their 95\% Cls are indicated by the diamonds. Test for heterogeneity: esophageal squamous cell carcinoma: $\mathrm{Q}=0.79, P=.85, \mathrm{I}^{2}=$ $0 \%$; esophageal adenocarcinoma: $Q=0.61, P=.74,\left.\right|^{2}=0 \%$. alcohol drinkers, those with the TT genotype had a significant 5.3-fold higher odds of gastric cardia adenocarcinoma compared with those with the CC/CT genotype. Likewise, Graziano et $\mathrm{al}^{61}$ found that alcohol drinkers with the TT genotype had a 5.4-fold higher odds of gastric cancer compared with nondrinkers with the CC genotype. In 2 studies of pancreatic cancer, ${ }^{67,68}$ the increased risk of pancreatic cancer associated with the TT or TT/CT genotypes was stronger in heavy drinkers and in heavy smokers than in nondrinkers and nonsmokers. In a study in China, ${ }^{63}$ smokers with the $T T / C T$ genotypes had a 7.7 -fold higher odds of gastric cancer compared with nonsmokers with the CC genotype. Two studies found no significant interaction between dietary folate intake and C677T in relation to esophageal squamous cell carcinoma ${ }^{28}$ or gastric cancer. ${ }^{66}$

MTHFR A1298C. Gao et al. ${ }^{70}$ found that alcohol drinkers with the $\mathrm{C}$ allele had a 2.9-fold higher odds of esophageal cancer compared with individuals with low alcohol con- sumption and the $A A$ genotype and that smokers with the $\mathrm{C}$ allele had a 3.5-fold higher odds of esophageal cancer compared with nonsmokers with the $A A$ genotype. No significant interaction between $A 1298 \mathrm{C}$ and smoking in relation to pancreatic cancer was observed in a US study. ${ }^{69}$

\section{Discussion}

Results of this meta-analysis of observational studies support a significant inverse association of dietary folate intake with risk of esophageal squamous cell carcinoma, esophageal adenocarcinoma, and pancreatic cancer. Summary results indicate that individuals with a high dietary folate intake are about $40 \%-50 \%$ less likely to develop these cancers compared with those with low intake. In support of a role of folate in the etiology of esophageal and pancreatic cancer, most but not all studies reported increased risk of these cancers associated with

\section{Gastric cancer}

Figure 3. RRs and $95 \%$ Cls of gastric cancer for highest versus lowest dietary folate intake category in individual case-control and cohort studies and all studies combined. The size of the data markers (squares) represents the statistical weight that each study contributed to the random-effects summary estimate; horizontal lines represent the 95\% Cls. The summary RR and the subtotals for each study design and their 95\% Cls are indicated by the diamonds. Test for heterogeneity among all studies: $\mathrm{Q}=24.27, P=.007, \mathrm{I}^{2}=$ $58.8 \%$; case-control studies: $\mathrm{Q}=$ $22.67, P=.004, I^{2}=64.7 \%$; cohort studies: $\mathrm{Q}=0.01, P=.91, \mathrm{l}^{2}$ $=0 \%$.

\section{Case-control studies} La Vecchia et al. $1994^{38}$ Harrison et al. $1997^{19}$ Lopez-Carillo et al. $1999^{40}$ Muñoz et al. $2001^{41}$ Mayne et al. $2001^{20}$ Chen et al. $2002^{31}$ Nomura et al. $2003^{21}$ Lissowska et al. $2004^{42}$ Kim et al. $2005^{43}$ Subtotal

\section{Cohort studies}

Botterweck et al. $2000^{44}$ Larsson et al. $2006^{45}$

Subtotal

Summary estimate

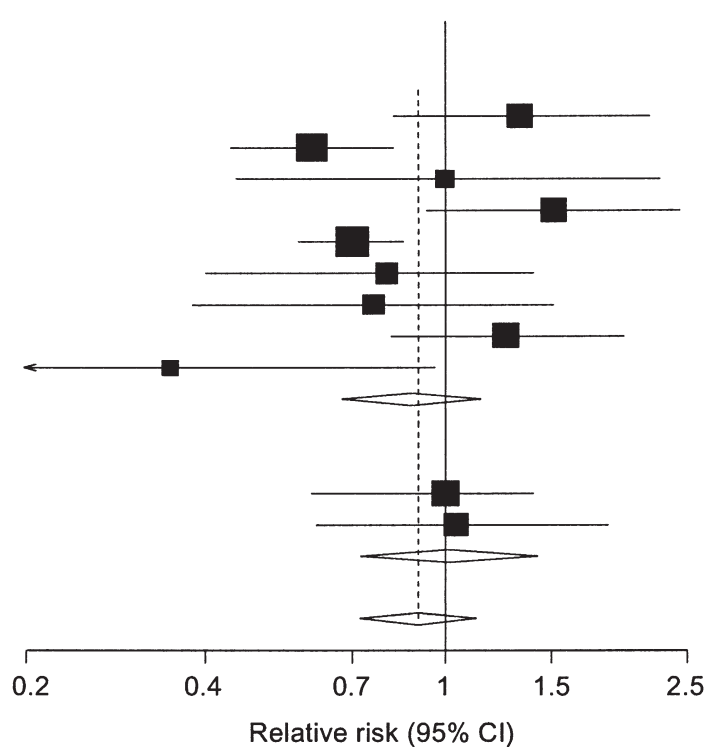

$\mathrm{RR}(95 \% \mathrm{Cl})$

$1.33(0.82-2.18)$

$0.60(0.44-0.82)$

$1.00(0.45-2.27)$

$1.51(0.93-2.45)$

$0.70(0.57-0.85)$

$0.80(0.40-1.40)$

$0.76(0.38-1.51)$

$1.26(0.81-1.98)$

$0.35(0.13-0.96)$

$0.88(0.67-1.14)$

$1.00(0.60-1.40)$

$1.04(0.61-1.86)$

$1.01(0.72-1.42)$

$0.90(0.72-1.13)$ 
Figure 4. RRs and $95 \% \mathrm{Cls}$ of pancreatic cancer for highest vs lowest dietary folate intake category in one case-control and 4 cohort studies and all studies combined. The size of the data markers (squares) represents the statistical weight that each study contributed to the random-effects summary estimate; horizontal lines represent the 95\% Cls. The summary RR and its 95\% Cl are indicated by the diamond. Test for heterogeneity: $Q=$ $4.83, P=.31,\left.\right|^{2}=17.1 \%$. ${ }^{*}$ Casecontrol study; the remaining are cohort studies. HPFS, Health Professionals Follow-up Study; NHS, Nurses' Health Study.
Pancreatic cancer

Baghurst et al. $1991^{47 \star}$

Stolzenberg-Solomon et al. $2001^{48}$

Skinner et al. 2004 (HPFS) $^{49}$

Skinner et al. 2004 (NHS) $)^{49}$

Larsson et al. $2006^{50}$

Summary estimate

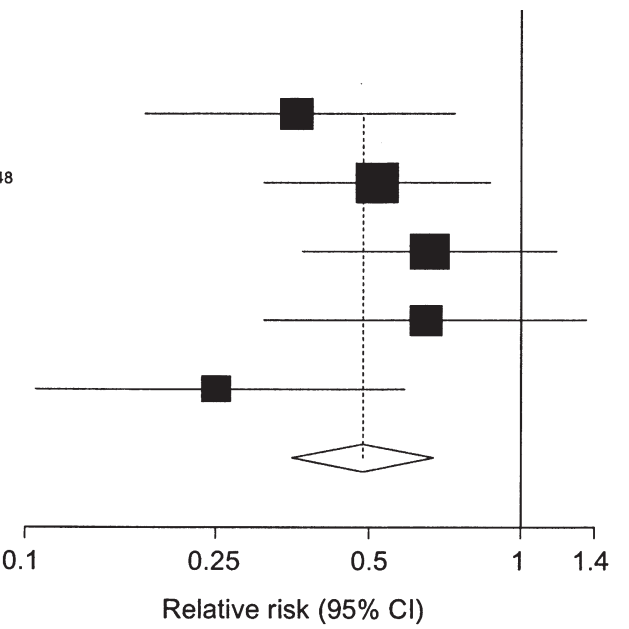

$\operatorname{RR}(95 \% \mathrm{Cl})$

$0.36(0.18-0.74)$

$0.52(0.31-0.87)$

$0.66(0.37-1.18)$

$0.65(0.31-1.35)$

$0.25(0.11-0.59)$

$0.49(0.35-0.67)$ the MTHFR 677TT genotype, which disrupts folate metabolism. Although there was no overall relation between dietary folate intake and risk of gastric cancer, there was evidence that the MTHFR 677TT genotype is associated with an increased risk. Summary results indicate that individuals with the TT genotype are about $70 \%$ and $90 \%$ more likely to develop gastric cancer (all sites) and gastric cardia adenocarcinoma, respectively, compared with those with the CC genotype. Several studies suggested that the relationship between the C677T polymorphism and cancer risk may be modified by alcohol or smoking, which may interfere with folate metabolism. ${ }^{10,12,71}$ The small number of subjects with the MTHFR 1298CC genotype in published studies limits the conclusion on this polymorphism.

The increased risk of esophageal, gastric, and pancreatic cancer associated with the MTHFR 677TT genotype suggests that aberrant DNA methylation may play a role in the development of these cancers. It has been shown that genomic DNA methylation is significantly lower in individuals with the $T T$ genotype compared with those with the CC genotype and that the methylation status in individuals with the TT genotype is directly correlated with red blood cell folate levels. ${ }^{72,73}$ Global genomic DNA hypomethylation, which is commonly observed in many cancers and in the early stages of carcinogenesis, may result in chromosomal instability, increased mutation rates, and activation of proto-oncogenes. , $^{3,74-77}$

As a meta-analysis of observational studies, our findings have several limitations. First, there is potential for recall bias from case-control studies, which represent the majority of studies included in this meta-analysis. Arguing against recall bias in case-control studies, however, for colorectal cancer (previous meta-analysis ${ }^{15}$ ) and pancreatic cancer, the results for dietary folate are very similar for cohort and case-control studies. A potential source of bias in studies of genotypes might be the inclusion of individuals from different ethnic backgrounds. ${ }^{78}$

Second, individual studies may have failed to control for potential confounders. A challenge when evaluating the association between folate intake and cancer risk relates to correlations between dietary folate and other nutrients, fiber, and phytochemicals in folate-rich plant foods. Greater consumption of folate-rich plant foods, such as fruits, vegetables, and whole grain cereals, has been associated with lower risk of esophageal, gastric, and pancreatic cancer in a number of case-control studies, ${ }^{79-81}$ although cohort studies are less supportive of such associations. ${ }^{80,82-85}$ High intake of folate and folate-rich foods may also reflect other factors related to a healthy lifestyle, such as never smoking, lower alcohol consumption, and lower body weight. Such healthy lifestyles have generally been associated with a reduced risk of gastrointestinal cancers. Although most studies controlled for these lifestyle factors, the possibility of residual confounding cannot be completely excluded. Only one study ${ }^{43}$ on dietary folate intake adjusted for Helicobacter pylori infection, which is an important risk factor for noncardia gastric cancer. ${ }^{86}$ In that study, ${ }^{43}$ the inverse association between dietary folate intake and gastric cancer risk was similar in $H$ pylori-infected individuals and in noninfected individuals. Although confounding is generally not anticipated in analyses of an association between a genotype and disease, there may be some imbalance in the distribution of risk factors by MTHFR genotypes. However, most studies controlled for potential risk factors. In addition, given the diversity of populations studied, the variety of cancers studied, and the different etiologies for cancers, uncontrolled confounding is unlikely to explain the strong associations with the MTHFR 677TT genotype.

A third limitation is that the method used to assess diet (food-frequency and recall questionnaires) will inevitably lead to some degree of misclassification of folate intake. Moreover, estimated folate intake from food may not accurately reflect the actual intake and absorption because folate is susceptible to heat, $\mathrm{pH}$, and oxidation. ${ }^{87}$ The impact of these measurement errors is most likely to be nondifferential misclassification, resulting in an underestimation of any true relationship. The few studies that have correlated reported folate intake with biochemical indicators of folate status have shown that foodfrequency questionnaires can provide valid information on folate intake. 88,89 Since 1998, flour and uncooked cereal-grain products in the United States have been fortified with folate. ${ }^{90}$ Although this could have resulted in misclassification of folate intake, only one of the US studies included years of study that covered prefortification and postfortification periods ${ }^{49}$ (Table 1).

Finally, as with any meta-analysis, publication bias could be of concern. Tests for publication bias in the literature on dietary folate intake and risk of esophageal, gastric, and pancreatic cancer were not statistically significant. However, there are many studies on folate-rich foods, such as fruits and vegetables, in relation to these cancers ${ }^{80}$ that were not included in this meta-analysis because they did not present results in terms of 
Table 2. Studies of the MTHFR C677T Polymorphism and Risk of Esophageal, Gastric, and Pancreatic Cancer

\begin{tabular}{|c|c|c|c|c|c|c|c|c|}
\hline \multirow[b]{2}{*}{ Reference } & \multirow[b]{2}{*}{ Country } & \multirow[b]{2}{*}{ Cases } & \multirow[b]{2}{*}{ Controls ${ }^{a}$} & \multicolumn{2}{|c|}{ MTHFR C677T genotype ${ }^{b}$} & \multirow{2}{*}{$\begin{array}{c}T T \\
\text { genotype } \\
(\%)^{c}\end{array}$} & \multirow[b]{2}{*}{ Adjustments } & \multirow{2}{*}{$\begin{array}{c}\text { Gene-environment } \\
\text { interaction }\end{array}$} \\
\hline & & & & $C T$ & $T T$ & & & \\
\hline \multicolumn{9}{|c|}{ Esophageal squamous cell carcinoma } \\
\hline Song et al, $2001^{53}$ & China & 240 & $360(P)$ & $3.14(1.94-5.08)$ & $6.18(3.32-11.51)$ & 17.2 & Age, sex, smoking & \multirow{3}{*}{$\begin{array}{l}\text { In alcohol drinkers } \\
\text { with } T T \text { vs } C C / \\
C T: \mathrm{RR}, 1.92 \\
\text { (95\% Cl, } 1.80- \\
4.58) ; P_{\text {interaction }} \\
=.32\end{array}$} \\
\hline $\begin{array}{l}\text { Stolzenberg- } \\
\text { Solomon et al, } \\
2003^{54}\end{array}$ & China & 129 & $398(\mathrm{P})$ & $0.86(0.68-2.26)$ & $1.24(0.68-2.26)$ & 31.2 & $\begin{array}{l}\text { Age, sex, trial, } \\
\text { BMI, smoking, } \\
\text { alcohol }\end{array}$ & \\
\hline Gao et al, $2004^{55}$ & China & $138^{d}$ & $223(P)$ & - & $1.56(0.88-2.79)^{e}$ & NA & $\begin{array}{l}\text { Age, sex, } \\
\text { smoking, and } \\
\text { intake of } \\
\text { alcohol, tea, } \\
\text { meat, pickled } \\
\text { vegetables, and } \\
\text { raw vegetables }\end{array}$ & \\
\hline $\begin{array}{l}\text { Zhang et al, } \\
2004^{56}\end{array}$ & China & 189 & $141(\mathrm{P})$ & $2.69(1.33-5.44)$ & $2.02(1.00-4.07)^{f}$ & 44.0 & Age, sex, smoking & \\
\hline $\begin{array}{l}\text { Zhang et al, } \\
\qquad 2004^{56}\end{array}$ & Germany & 241 & $256(P)$ & $1.15(0.79-1.68)$ & $1.04(0.60-1.81)^{f}$ & 13.3 & Age, sex, smoking & \\
\hline Yang et al, $2005^{28}$ & Japan & 165 & $495(H)$ & $0.97(0.63-1.49)$ & $0.66(0.35-1.25)$ & 16.2 & $\begin{array}{l}\text { Age, sex, } \\
\text { smoking, and } \\
\text { intake of } \\
\text { alcohol and } \\
\text { folate }\end{array}$ & $\begin{array}{l}\text { Significant } \\
\text { interaction with } \\
\text { heavy alcohol } \\
\text { drinking; no } \\
\text { significant } \\
\text { interactions } \\
\text { with folate or } \\
\text { smoking }\end{array}$ \\
\hline $\begin{array}{l}\text { Wang et al, } \\
2005^{57}\end{array}$ & China & 275 & $315(P)$ & $0.96(0.61-1.50)$ & $1.58(0.99-2.50)$ & 31.1 & Age, sex & \\
\hline \multicolumn{9}{|c|}{ Gastric cardia adenocarcinoma } \\
\hline Miao et al, $2002^{59}$ & China & 217 & $468(P)$ & $1.56(1.03-2.36)$ & $2.04(1.28-3.26)$ & 21.3 & Age, sex, smoking & \multirow{3}{*}{$\begin{array}{l}\text { In alcohol drinkers } \\
\text { with } T T \text { vs } C C / \\
C T: \mathrm{RR}, 5.32 \\
(95 \% \mathrm{Cl}, 1.66- \\
17.02) ; \\
P_{\text {interaction }}=.03\end{array}$} \\
\hline $\begin{array}{l}\text { Stolzenberg- } \\
\text { Solomon et al, } \\
2003^{54}\end{array}$ & China & 90 & $398(P)$ & $0.67(0.35-1.29)$ & $1.17(0.61-2.25)$ & 31.2 & $\begin{array}{l}\text { Age, sex, trial, } \\
\text { BMI, smoking, } \\
\text { alcohol }\end{array}$ & \\
\hline Shen et al, $2005^{60}$ & China & 125 & $313(P)$ & $0.95(0.59-1.52)$ & $2.60(1.30-5.21)$ & 8.9 & $\begin{array}{l}\text { Age, sex, } \\
\text { residential } \\
\text { area, smoking, } \\
\text { and intake of } \\
\text { alcohol and tea }\end{array}$ & \\
\hline $\begin{array}{l}\text { Wang et al, } \\
2005^{57}\end{array}$ & China & 129 & $315(P)$ & $0.81(0.45-1.47)$ & $1.58(0.88-2.83)$ & 31.1 & Age, sex & \\
\hline $\begin{array}{l}\text { Graziano et al, } \\
2006^{61}\end{array}$ & Italy & 43 & $164(\mathrm{H})$ & $3.62(1.46-8.98)$ & $3.71(1.30-10.57)$ & 17.7 & Age, sex & \\
\hline \multicolumn{9}{|c|}{ Noncardia gastric cancer } \\
\hline $\begin{array}{c}\text { Graziano et al, } \\
2006^{61}\end{array}$ & Italy & 119 & $164(\mathrm{H})$ & $2.32(1.31-4.12)$ & $2.74(1.39-5.42)$ & 17.7 & Age, sex & \\
\hline \multicolumn{9}{|c|}{ Gastric cancer (all sites) } \\
\hline Gao et al, $2002^{63}$ & China & 107 & $200(P)$ & - & $1.89(1.08-3.32)^{g}$ & NA & Age, sex & $\begin{array}{l}\text { In smokers with } \\
T T / C T \text { vs } \\
\text { nonsmokers } \\
\text { with } C C: \mathrm{RR} \text {, } \\
7.72(95 \% \mathrm{Cl} \text {, } \\
2.23-26.79) \\
\text { In alcohol drinkers } \\
\text { with } T T / C T \text { vs } \\
\text { nondrinkers } \\
\text { with } C C: \mathrm{RR}, \\
3.08(95 \% \mathrm{Cl} \text {, } \\
1.30-7.23)\end{array}$ \\
\hline Mu et al, $2004^{64}$ & China & 194 & $391(P)$ & $1.44(0.96-2.15)$ & $1.80(1.07-3.04)$ & 14.6 & Age & $\begin{array}{l}\text { In smokers with } \\
\text { TT/CT vs CC: } \\
\text { RR, } 2.83 \\
\text { (1.39-5.74); no } \\
\text { interaction with } \\
\text { alcohol }\end{array}$ \\
\hline Shen et al, $2005^{60}$ & China & 320 & $313(P)$ & $1.07(0.76-1.51)$ & $1.79(1.02-3.15)$ & 8.9 & $\begin{array}{l}\text { Age, sex, } \\
\text { residential } \\
\text { area, smoking, } \\
\text { and intake of } \\
\text { alcohol and tea }\end{array}$ & \\
\hline Kim et al, $2005^{65}$ & Korea & 133 & $445(P)$ & $0.92(0.58-1.47)$ & $1.15(0.85-1.55)$ & 14.2 & Age, sex & \\
\hline
\end{tabular}


Table 2 (continued). Studies of the MTHFR C677T Polymorphism and Risk of Esophageal, Gastric, and Pancreatic Cancer

\begin{tabular}{|c|c|c|c|c|c|c|c|c|}
\hline \multirow[b]{2}{*}{ Reference } & \multirow[b]{2}{*}{ Country } & \multirow[b]{2}{*}{ Cases } & \multirow[b]{2}{*}{ Controlsa } & \multicolumn{2}{|c|}{ MTHFR C677T genotype ${ }^{b}$} & \multirow{2}{*}{$\begin{array}{c}T T \\
\text { genotype } \\
(\%)^{c}\end{array}$} & \multirow[b]{2}{*}{ Adjustments } & \multirow{2}{*}{$\begin{array}{l}\text { Gene-environment } \\
\text { interaction }\end{array}$} \\
\hline & & & & CT & $T T$ & & & \\
\hline $\begin{array}{l}\text { Graziano et al, } \\
2006^{61}\end{array}$ & Italy & 162 & $164(H)$ & $(1.52-4.37)$ & $(1.57-5.55)$ & & Age, sex & $\begin{array}{l}\text { In alcohol drinkers with } \\
\text { TT vs nondrinkers } \\
\text { with CC: RR, } 5.36 \\
\text { (95\% Cl, } \\
\text { 1.94-14.83); } \\
P_{\text {interaction }}=.09\end{array}$ \\
\hline $\begin{array}{l}\text { Lacasaña-Navarro } \\
\text { et al, } 2006^{6}\end{array}$ & Mexico & 201 & $427(\mathrm{H})$ & $1.24(0.81-1.90)$ & $1.62(1.00-2.59)$ & 24.4 & $\begin{array}{l}\text { Age, sex, } \\
\text { education, } H \\
\text { pylori, energy } \\
\text { and capsaicin } \\
\text { intake }\end{array}$ & $\begin{array}{l}\text { No significant } \\
\text { interactions with } \\
\text { folate }(P=.16) \text { or } \\
\text { alcohol }(P=.36)\end{array}$ \\
\hline \multicolumn{9}{|l|}{ Pancreatic cancer } \\
\hline Li et al, $2005^{67}$ & $\begin{array}{l}\text { United } \\
\text { States } \\
\text { (white) }\end{array}$ & 347 & $348(H)$ & $0.90(0.63-1.27)$ & $2.14(1.14-4.01)$ & 6.5 & $\begin{array}{l}\text { Age, smoking, } \\
\text { history of } \\
\text { pancreatitis } \\
\text { and diabetes }\end{array}$ & $\begin{array}{l}\text { In heavy smokers with } \\
T T \text { vs never smokers } \\
\text { with CC/CT: RR, } \\
6.83(95 \% \mathrm{Cl}, 1.91- \\
24.38) \\
\text { In heavy alcohol } \\
\text { drinkers with } T T \text { vs } \\
\text { nondrinkers with } \\
\text { CC/CT: RR, } 4.23 \\
\text { (95\% Cl, } 0.88-20.3)\end{array}$ \\
\hline $\begin{array}{l}\text { Wang et al, } \\
2005^{68}\end{array}$ & China & 163 & $337(\mathrm{P})$ & $2.60(1.61-4.29)$ & $5.12(2.94-9.10)$ & 15.7 & $\begin{array}{l}\text { Age, sex, } \\
\text { smoking, } \\
\text { drinking status }\end{array}$ & $\begin{array}{l}\text { In heavy smokers with } \\
T T / C T \text { vs } \\
\text { nonsmokers with } \\
\text { CC: RR, } 6.69 \text { (95\% } \\
\text { Cl, 3.39-13.63) } \\
\text { In alcohol drinkers with } \\
T T / C T \text { vs nondrinkers } \\
\text { with CC: RR, } \\
4.39 \text { (95\% Cl, 2.25- } \\
\text { 8.78) }\end{array}$ \\
\hline $\begin{array}{l}\text { Matsubayashi } \\
\text { et al, } 2005^{69}\end{array}$ & $\begin{array}{l}\text { United } \\
\text { States (all } \\
\text { ethnicities) }\end{array}$ & 303 & $305(\mathrm{H})$ & $0.79(0.56-1.11)^{d}$ & $1.10(0.67-1.82)^{d}$ & 11.8 & Age, sex, ethnicity & $\begin{array}{l}\text { No significant } \\
\text { interaction with } \\
\text { smoking }\end{array}$ \\
\hline
\end{tabular}

BMI, body mass index; NA, not available.

aType of controls in parentheses $(\mathrm{H}=$ hospital-based; $\mathrm{P}=$ population-based).

${ }^{b}$ The $C C$ genotype is the reference. Values are ORs with $95 \% \mathrm{Cls}$.

cPrevalence of $T T$ genotype among controls.

${ }^{d}$ All histologic subtypes.

${ }^{e}$ Combined $T T$ and $C T$ genotypes. The RR (and its $95 \% \mathrm{Cl}$ ) was derived by pooling the RRs across strata of the thymidylate synthase $3^{\prime}-U T R$ polymorphism.

${ }^{f}$ Calculated from the provided data.

sCombined TT and CT genotypes.

Figure 5. ORs and 95\% Cls of esophageal, gastric, and pancreatic cancer for MTHFR $677 T T$ vs CC genotype in individual case-control studies.
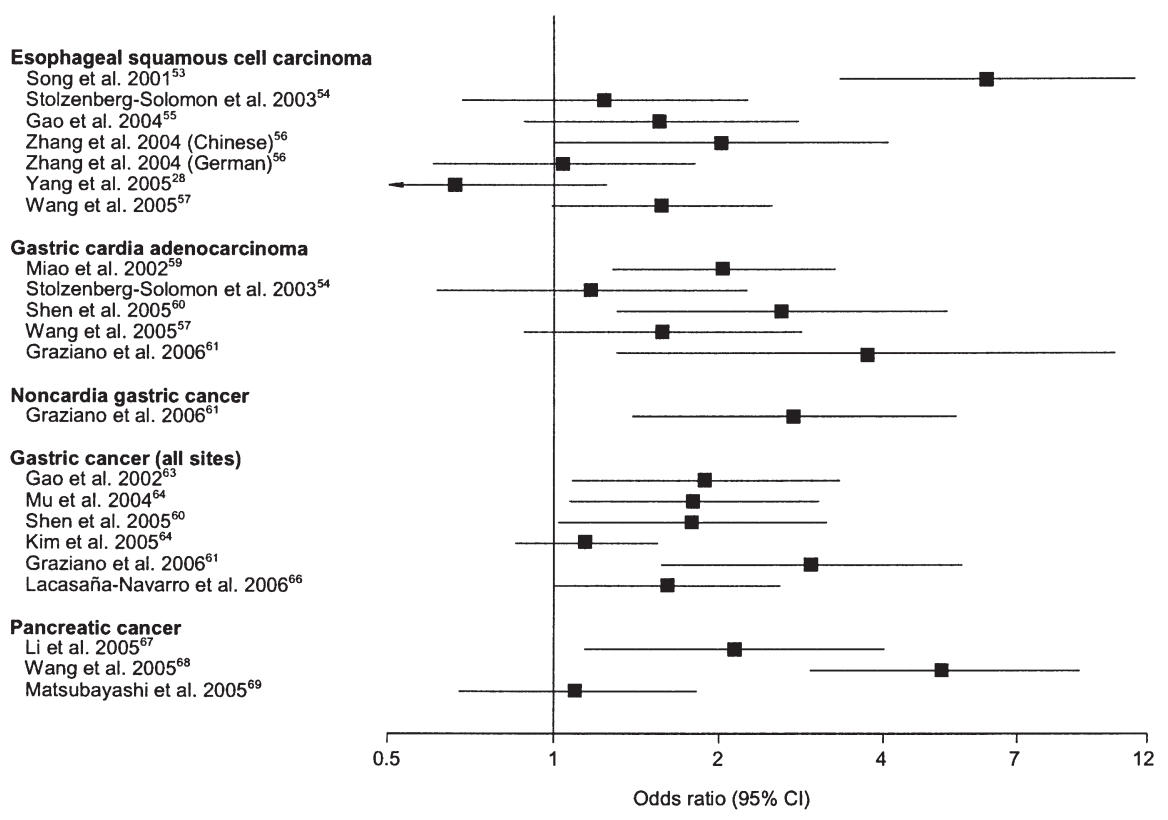

OR $(95 \% \mathrm{Cl})$

$6.18(3.32-11.5)$ $1.24(0.68-2.26)$ $1.56(0.88-2.79)$ $2.02(1.00-4.07)$ $1.04(0.60-1.81)$ $0.66(0.35-1.25)$ $1.58(0.99-2.50)$

$2.04(1.28-3.26)$ $1.17(0.61-2.25)$ $2.60(1.30-5.21$ $1.58(0.88-2.83)$

$2.74(1.39-5.42)$

$1.89(1.08-3.32)$ $1.80(1.07-3.04$

$1.79(1.02-3.15)$

$1.15(0.85-1.55)$

$2.95(1.57-5.55)$

$1.62(1.00-2.59)$

$2.14(1.14-4.01)$ $5.12(2.94-9.10)$ $1.10(0.67-1.82)$ 
Table 3. Studies of the MTHFR A1298C Polymorphism and Risk of Esophageal, Gastric, and Pancreatic Cancer

\begin{tabular}{|c|c|c|c|c|c|c|c|}
\hline \multirow[b]{2}{*}{ Reference } & \multirow[b]{2}{*}{ Country } & \multirow[b]{2}{*}{ Cases } & \multirow[b]{2}{*}{ Controls ${ }^{a}$} & \multicolumn{2}{|c|}{ MTHFR A1298C genotype ${ }^{b}$} & \multirow{2}{*}{$\begin{array}{c}C C \\
\text { genotype } \\
(\%)^{c}\end{array}$} & \multirow[b]{2}{*}{ Adjustments } \\
\hline & & & & $A C$ & $C C$ & & \\
\hline \multicolumn{8}{|c|}{ Esophageal squamous cell carcinoma } \\
\hline Song et al, $2001^{53}$ & China & 240 & $360(P)$ & $0.88(0.59-1.32)$ & $4.43(1.23-16.02)$ & 1.4 & Age, sex, smoking \\
\hline $\begin{array}{l}\text { Stolzenberg-Solomon et al, } \\
2003^{54}\end{array}$ & China & 129 & $398(P)$ & $0.92(0.57-1.48)$ & $-^{d}$ & 0 & $\begin{array}{l}\text { Age, sex, trial, BMI, smoking, } \\
\text { alcohol }\end{array}$ \\
\hline Gao et al, $2004^{70}$ & China & $141^{e}$ & $228(P)$ & $1.14(0.72-1.79)$ & $\simeq^{d}$ & 0 & Age \\
\hline \multicolumn{8}{|l|}{ Gastric cardia cancer } \\
\hline Miao et al, $2002^{59}$ & China & 217 & $468(P)$ & $1.19(0.81-1.74)$ & $2.41(0.51-11.37)$ & 1.1 & Age, sex, smoking \\
\hline $\begin{array}{l}\text { Stolzenberg-Solomon et al, } \\
2003^{54}\end{array}$ & China & 90 & $398(P)$ & $0.78(0.45-1.34)$ & $-^{d}$ & 0 & $\begin{array}{l}\text { Age, sex, trial, BMI, smoking, } \\
\text { alcohol }\end{array}$ \\
\hline Shen et al, $2005^{60}$ & China & 125 & $313(P)$ & $0.77(0.46-1.30)$ & $-^{d}$ & 3.2 & $\begin{array}{l}\text { Age, sex, residential area, } \\
\text { smoking, and intake of } \\
\text { alcohol and tea }\end{array}$ \\
\hline \multicolumn{8}{|l|}{ Gastric cancer (all sites) } \\
\hline Kim et al, $2005^{65}$ & Korea & 133 & $445(P)$ & $1.11(0.70-1.78)$ & $0.83(0.28-2.45)$ & 1.8 & Age, sex \\
\hline Shen et al, $2005^{60}$ & China & 320 & $313(P)$ & $1.30(0.90-1.87)$ & $0.92(0.35-2.42)$ & 3.2 & $\begin{array}{l}\text { Age, sex, residential area, } \\
\text { smoking, and intake of } \\
\text { alcohol and tea }\end{array}$ \\
\hline \multicolumn{8}{|l|}{ Pancreatic cancer } \\
\hline Li et al, $2005^{67}$ & $\begin{array}{l}\text { United States } \\
\quad \text { (white) }\end{array}$ & 347 & $348(\mathrm{H})$ & $1.12(0.79-1.60)$ & $0.77(0.44-1.34)$ & 12.9 & $\begin{array}{l}\text { Age, smoking, history of } \\
\text { pancreatitis and diabetes }\end{array}$ \\
\hline Wang et al, $2005^{68}$ & China & 163 & $337(\mathrm{P})$ & $0.86(0.54-1.33)$ & $0.48(0.07-1.97)$ & 2.4 & $\begin{array}{l}\text { Age, sex, smoking, drinking } \\
\text { status }\end{array}$ \\
\hline $\begin{array}{l}\text { Matsubayashi et al, } \\
2005^{69}\end{array}$ & $\begin{array}{l}\text { United States } \\
\quad \text { (all ethnicities) }\end{array}$ & 303 & $305(\mathrm{H})$ & $1.04(0.74-1.45)^{f}$ & $1.86(1.04-3.32)^{f}$ & 6.9 & Age, sex, and ethnicity \\
\hline
\end{tabular}

BMI, body mass index.

aType of controls in parentheses $(\mathrm{H}$, hospital-based; $\mathrm{P}$, population-based).

${ }^{b}$ The $A A$ genotype is the reference. Values are ORs with $95 \% \mathrm{Cls}$.

cPrevalence of $C C$ genotype among controls.

वThere were no cases (or only one case ${ }^{60}$ ) or controls with this genotype.

eAll histologic subtypes.

${ }^{f}$ Calculated from the provided data.

folate. Statistical testing suggested the presence of publication bias in the published literature examining the association of the MTHFR C677T polymorphism with gastric cancer risk. Adjusting for possible unpublished studies slightly attenuated the relation between the $T T$ genotype and gastric cancer risk, but the association remained statistically significant.

Although findings of this meta-analysis suggest that increased consumption of foods naturally rich in folate may be beneficial, they do not encourage increased use of dietary supplements for cancer prevention. Three prospective studies have reported results on supplemental folate intake in relation to risk of pancreatic cancer. ${ }^{48-50}$ All 3 studies observed an inverse association between dietary folate intake and pancreatic cancer risk, but none indicated an inverse relation with supplemental folate intake. Furthermore, a previous meta-analysis showed that intake of dietary folate, but not of total folate, was inversely associated with colorectal cancer risk. ${ }^{15}$ Studies in animals suggest that the effect of folate on carcinogenesis may depend on the dose and timing of exposure, with folate deficiency enhancing carcinogenesis in normal cells but folate supplementation enhancing progression of existing tumor cells. ${ }^{91}$

In summary, this systematic review supports the hypothesis that folate may play a role in the etiology of esophageal, gastric, and pancreatic cancer. Large studies that assess the interrelations between folate, alcohol, smoking, and genetic polymorphisms in the folate metabolic pathway are needed to further clarify the role of folate deficiency and folate metabolism in the development of these cancers.

\section{References}

1. Blount BC, Mack MM, Wehr CM, MacGregor JT, Hiatt RA, Wang G, Wickramasinghe SN, Everson RB, Ames BN. Folate deficiency causes uracil misincorporation into human DNA and chromosome breakage: implications for cancer and neuronal damage. Proc Natl Acad Sci U S A 1997;94:3290-3295.

2. Choi SW, Mason JB. Folate and carcinogenesis: an integrated scheme. J Nutr 2000;130:129-132.

3. Kim YI. Folate and DNA methylation: a mechanistic link between folate deficiency and colorectal cancer? Cancer Epidemiol Biomarkers Prev 2004;13:511-519.

4. Frosst $P$, Blom $H J$, Milos R, Goyette $P$, Sheppard CA, Matthews RG, Boers GJ, den Heijer M, Kluijtmans LA, van den Heuvel LP, et al. A candidate genetic risk factor for vascular disease: a common mutation in methylenetetrahydrofolate reductase. Nat Genet 1995;10:111-113.

5. Weisberg I, Tran P, Christensen B, Sibani S, Rozen R. A second genetic polymorphism in methylenetetrahydrofolate reductase (MTHFR) associated with decreased enzyme activity. Mol Genet Metab 1998;64:169-172.

6. Friedman G, Goldschmidt N, Friedlander Y, Ben-Yehuda A, Selhub J, Babaey S, Mendel M, Kidron M, Bar-On H. A common mutation A1298C in human methylenetetrahydrofolate reductase gene: association with plasma total homocysteine and folate concentrations. J Nutr 1999;129:1656-1661.

7. Klerk M, Verhoef P, Clarke R, Blom HJ, Kok FJ, Schouten EG. MTHFR $677 \mathrm{C} \rightarrow$ T polymorphism and risk of coronary heart disease: a meta-analysis. JAMA 2002;288:2023-2031.

8. Ma J, Stampfer MJ, Christensen B, Giovannucci E, Hunter DJ, Chen J, Willett WC, Selhub J, Hennekens CH, Gravel R, Rozen R. A polymorphism of the methionine synthase gene: association with plasma folate, vitamin B12, homocyst(e)ine, and colorectal 
cancer risk. Cancer Epidemiol Biomarkers Prev 1999;8: 825-829.

9. Lievers KJ, Boers GH, Verhoef P, den Heijer M, Kluijtmans LA, van der Put NM, Trijbels FJ, Blom HJ. A second common variant in the methylenetetrahydrofolate reductase (MTHFR) gene and its relationship to MTHFR enzyme activity, homocysteine, and cardiovascular disease risk. J Mol Med 2001;79:522-528.

10. Bailey LB. Folate status assessment. J Nutr 1990;120(suppl 11):1508-1511.

11. Bailey LB. Folate, methyl-related nutrients, alcohol, and the MTHFR $677 \mathrm{C} \rightarrow$ T polymorphism affect cancer risk: intake recommendations. J Nutr 2003;133:3748S-3753S.

12. Halsted $\mathrm{CH}$, Villanueva JA, Devlin AM, Chandler CJ. Metabolic interactions of alcohol and folate. J Nutr 2002;132:2367S2372S.

13. Barak AJ, Beckenhauer HC, Tuma DJ, Badakhsh S. Effects of prolonged ethanol feeding on methionine metabolism in rat liver. Biochem Cell Biol 1987;65:230-233.

14. Chiuve SE, Giovannucci EL, Hankinson SE, Hunter DJ, Stampfer MJ, Willett WC, Rimm EB. Alcohol intake and methylenetetrahydrofolate reductase polymorphism modify the relation of folate intake to plasma homocysteine. Am J Clin Nutr 2005;82:155162.

15. Sanjoaquin MA, Allen N, Couto E, Roddam AW, Key TJ. Folate intake and colorectal cancer risk: a meta-analytical approach. Int J Cancer 2005;113:825-828.

16. Kono S, Chen K. Genetic polymorphisms of methylenetetrahydrofolate reductase and colorectal cancer and adenoma. Cancer Sci 2005;96:535-542.

17. Greenland S. Quantitative methods in the review of epidemiologic literature. Epidemiol Rev 1987;9:1-30.

18. DerSimonian R, Laird N. Meta-analysis in clinical trials. Controlled Clin Trials 1986;7:177-188.

19. Harrison LE, Zhang ZF, Karpeh MS, Sun M, Kurtz RC. The role of dietary factors in the intestinal and diffuse histologic subtypes of gastric adenocarcinoma: a case-control study in the U.S. Cancer 1997;80:1021-1028.

20. Mayne ST, Risch HA, Dubrow R, Chow WH, Gammon MD, Vaughan TL, Farrow DC, Schoenberg JB, Stanford JL, Ahsan H, West AB, Rotterdam H, Blot WJ, Fraumeni JF Jr. Nutrient intake and risk of subtypes of esophageal and gastric cancer. Cancer Epidemiol Biomarkers Prev 2001;10:1055-1062.

21. Nomura AM, Hankin JH, Kolonel LN, Wilkens LR, Goodman MT, Stemmermann GN. Case-control study of diet and other risk factors for gastric cancer in Hawaii (United States). Cancer Causes Control 2003;14:547-558.

22. Higgins JP, Thompson SG. Quantifying heterogeneity in a metaanalysis. Stat Med 2002;21:1539-1558.

23. van Houwelingen HC, Arends LR, Stijnen T. Advanced methods in meta-analysis: multivariate approach and meta-regression. Stat Med 2002;21:589-624.

24. Thompson SG, Sharp SJ. Explaining heterogeneity in meta-analysis: a comparison of methods. Stat Med 1999;18:2693-2708.

25. Egger M, Davey Smith G, Schneider M, Minder C. Bias in metaanalysis detected by a simple, graphical test. BMJ 1997;315: 629-634.

26. Duval S, Tweedie R. Trim and fill: a simple funnel-plot-based method of testing and adjusting for publication bias in metaanalysis. Biometrics 2000;56:455-463.

27. Brown LM, Blot WJ, Schuman SH, Smith VM, Ershow AG, Marks RD, Fraumeni JF, Jr. Environmental factors and high risk of esophageal cancer among men in coastal South Carolina. J Natl Cancer Inst 1988;80:1620-1625.

28. Yang CX, Matsuo K, Ito H, Shinoda M, Hatooka S, Hirose K, Wakai K, Saito T, Suzuki T, Maeda T, Tajima K. Gene-environment interactions between alcohol drinking and the MTHFR C677T polymorphism impact on esophageal cancer risk: re- sults of a case-control study in Japan. Carcinogenesis 2005;26:1285-1290.

29. Galeone C, Pelucchi C, Levi F, Negri E, Talamini R, Franceschi S, La Vecchia C. Folate intake and squamous-cell carcinoma of the oesophagus in Italian and Swiss men. Ann Oncol 2006;17:521525.

30. Zhang ZF, Kurtz RC, Yu GP, Sun M, Gargon N, Karpeh M Jr, Fein JS, Harlap S. Adenocarcinomas of the esophagus and gastric cardia: the role of diet. Nutr Cancer 1997;27:298-309.

31. Chen H, Tucker KL, Graubard BI, Heineman EF, Markin RS, Potischman NA, Russell RM, Weisenburger DD, Ward MH. Nutrient intakes and adenocarcinoma of the esophagus and distal stomach. Nutr Cancer 2002;42:33-40.

32. De Stefani E, Ronco A, Mendilaharsu M, Deneo-Pellegrini H. Diet and risk of cancer of the upper aerodigestive tract-II. Nutrients. Oral Oncol 1999;35:22-26.

33. Brown LM, Swanson CA, Gridley G, Swanson GM, Schoenberg JB, Greenberg RS, Silverman DT, Pottern LM, Hayes RB, Schwartz $A G$, et al. Adenocarcinoma of the esophagus: role of obesity and diet. J Natl Cancer Inst 1995;87:104-109.

34. Brown LM, Swanson CA, Gridley G, Swanson GM, Silverman DT, Greenberg RS, Hayes RB, Schoenberg JB, Pottern LM, Schwartz AG, Liff JM, Hoover R, Fraumeni JF Jr. Dietary factors and the risk of squamous cell esophageal cancer among black and white men in the United States. Cancer Causes Control 1998;9:467-474.

35. Franceschi S, Bidoli E, Negri E, Zambon P, Talamini R, Ruol A, Parpinel M, Levi F, Simonato L, La Vecchia C. Role of macronutrients, vitamins and minerals in the aetiology of squamous-cell carcinoma of the oesophagus. Int J Cancer 2000;86:626-631.

36. Bollschweiler E, Wolfgarten E, Nowroth T, Rosendahl U, Monig $\mathrm{SP}$, Holscher AH. Vitamin intake and risk of subtypes of esophageal cancer in Germany. J Cancer Res Clin Oncol 2002;128: 575-580.

37. González CA, Riboli E, Badosa J, Batiste E, Cardona T, Pita S, Sanz JM, Torrent M, Agudo A. Nutritional factors and gastric cancer in Spain. Am J Epidemiol 1994;139:466-473.

38. La Vecchia C, Ferraroni M, D'Avanzo B, Decarli A, Franceschi S. Selected micronutrient intake and the risk of gastric cancer. Cancer Epidemiol Biomarkers Prev 1994;3:393-398.

39. Muñoz SE, Ferraroni M, La Vecchia C, Decarli A. Gastric cancer risk factors in subjects with family history. Cancer Epidemiol Biomarkers Prev 1997;6:137-140.

40. Lopez-Carrillo L, Lopez-Cervantes M, Ward MH, Bravo-Alvarado J, Ramirez-Espitia A. Nutrient intake and gastric cancer in Mexico. Int J Cancer 1999;83:601-605.

41. Muñoz N, Plummer M, Vivas J, Moreno V, De Sanjosé S, Lopez G, Oliver W. A case-control study of gastric cancer in Venezuela. Int J Cancer 2001;93:417-423.

42. Lissowska J, Gail MH, Pee D, Groves FD, Sobin LH, NasierowskaGuttmejer A, Sygnowska E, Zatonski W, Blot WJ, Chow WH. Diet and stomach cancer risk in Warsaw, Poland. Nutr Cancer 2004; 48:149-159.

43. Kim HJ, Kim MK, Chang WK, Choi HS, Choi BY, Lee SS. Effect of nutrient intake and Helicobacter pylori infection on gastric cancer in Korea: a case-control study. Nutr Cancer 2005;52:138-146.

44. Botterweck AA, van den Brandt PA, Goldbohm RA. Vitamins, carotenoids, dietary fiber, and the risk of gastric carcinoma: results from a prospective study after 6.3 years of follow-up. Cancer 2000;88:737-748.

45. Larsson SC, Giovannucci E, Wolk A. Folate intake and stomach cancer incidence in a prospective cohort of Swedish women. Cancer Epidemiol Biomarkers Prev 2006;15:1409-1412.

46. Silverman DT, Swanson CA, Gridley G, Wacholder S, Greenberg RS, Brown LM, Hayes RB, Swanson GM, Schoenberg JB, Pottern LM, Schwartz AG, Fraumeni JF Jr, Hoover RN. Dietary and nutritional factors and pancreatic cancer: a case-control study based on direct interviews. J Natl Cancer Inst 1998;90:1710-1719. 
47. Baghurst PA, McMichael AJ, Slavotinek AH, Baghurst KI, Boyle P, Walker AM. A case-control study of diet and cancer of the pancreas. Am J Epidemiol 1991;134:167-179.

48. Stolzenberg-Solomon RZ, Pietinen P, Barrett MJ, Taylor PR, Virtamo J, Albanes D. Dietary and other methyl-group availability factors and pancreatic cancer risk in a cohort of male smokers. Am J Epidemiol 2001;153:680-687.

49. Skinner HG, Michaud DS, Giovannucci EL, Rimm EB, Stampfer MJ, Willett WC, Colditz GA, Fuchs CS. A prospective study of folate intake and the risk of pancreatic cancer in men and women. Am J Epidemiol 2004;160:248-258.

50. Larsson SC, Håkansson N, Giovannucci E, Wolk A. Folate intake and pancreatic cancer incidence: a prospective study of Swedish women and men. J Natl Cancer Inst 2006;98:407-413.

51. Tan W, Miao X, Wang L, Yu C, Xiong P, Liang G, Sun T, Zhou Y, Zhang $X$, Li H, Lin D. Significant increase in risk of gastroesophageal cancer is associated with interaction between promoter polymorphisms in thymidylate synthase and serum folate status. Carcinogenesis 2005;26:1430-1435.

52. Stolzenberg-Solomon RZ, Albanes D, Nieto FJ, Hartman TJ, Tangrea JA, Rautalahti M, Sehlub J, Virtamo J, Taylor PR. Pancreatic cancer risk and nutrition-related methyl-group availability indicators in male smokers. J Natl Cancer Inst 1999;91:535-541.

53. Song C, Xing D, Tan W, Wei Q, Lin D. Methylenetetrahydrofolate reductase polymorphisms increase risk of esophageal squamous cell carcinoma in a Chinese population. Cancer Res 2001;61: 3272-3275.

54. Stolzenberg-Solomon RZ, Qiao YL, Abnet CC, Ratnasinghe DL, Dawsey SM, Dong ZW, Taylor PR, Mark SD. Esophageal and gastric cardia cancer risk and folate- and vitamin B(12)-related polymorphisms in Linxian, China. Cancer Epidemiol Biomarkers Prev 2003;12:1222-1226.

55. Gao CM, Takezaki T, Wu JZ, Liu YT, Ding JH, Li SP, Su P, Hu X, Kai HT, Li ZY, Matsuo K, Hamajima N, Sugimura H, Tajima K. Polymorphisms in thymidylate synthase and methylenetetrahydrofolate reductase genes and the susceptibility to esophageal and stomach cancer with smoking. Asian Pac J Cancer Prev 2004;5: 133-138.

56. Zhang J, Zotz RB, Li Y, Wang R, Kiel S, Schulz WA, Wen D, Chen Z, Zhang L, Wang S, Gabbert HE, Sarbia M. Methylenetetrahydrofolate reductase C677T polymorphism and predisposition towards esophageal squamous cell carcinoma in a German Caucasian and a northern Chinese population. J Cancer Res Clin Oncol 2004;130:574-580.

57. Wang LD, Guo RF, Fan ZM, He X, Gao SS, Guo HQ, Matsuo K, Yin $\mathrm{LM}$, Li JL. Association of methylenetetrahydrofolate reductase and thymidylate synthase promoter polymorphisms with genetic susceptibility to esophageal and cardia cancer in a Chinese high-risk population. Dis Esophagus 2005;18:177-184.

58. Shen H, Xu Y, Zheng Y, Qian Y, Yu R, Qin Y, Wang X, Spitz MR, Wei Q. Polymorphisms of 5,10-methylenetetrahydrofolate reductase and risk of gastric cancer in a Chinese population: a casecontrol study. Int J Cancer 2001;95:332-336.

59. Miao X, Xing D, Tan W, Qi J, Lu W, Lin D. Susceptibility to gastric cardia adenocarcinoma and genetic polymorphisms in methylenetetrahydrofolate reductase in an at-risk Chinese population. Cancer Epidemiol Biomarkers Prev 2002;11:1454-1458.

60. Shen H, Newmann AS, Hu Z, Zhang Z, Xu Y, Wang L, Hu X, Guo J, Wang X, Wei Q. Methylenetetrahydrofolate reductase polymorphisms/haplotypes and risk of gastric cancer: a case-control analysis in China. Oncol Rep 2005;13:355-360.

61. Graziano F, Kawakami K, Ruzzo A, Watanabe G, Santini D, Pizzagalli F, Bisonni R, Mari D, Floriani I, Catalano V, Silva R, Tonini G, Torri V, Giustini L, Magnani M. Methylenetetrahydrofolate reductase $677 \mathrm{C} / \mathrm{T}$ gene polymorphism, gastric cancer susceptibility and genomic DNA hypomethylation in an at-risk Italian population. Int J Cancer 2006;118:628-632.
62. Gao CM, Wu JZ, Liu YT, Ding JH, Li SP, Su P, Hu X, Kai HT, Toshiro $\mathrm{T}$, Kazuo T. [Interactions between lifestyle, methylanetetrahydrofolate reductase gene and polymorphisms in thymidylate synthase gene with risk of stomach cancer]. Zhonghua Liu Xing Bing Xue Za Zhi 2003;24:599-603.

63. Gao C, Wu J, Ding J, Liu Y, Zang Y, Li S, Su P, Hu X, Xu T, Toshiro $\mathrm{T}$, Kazuo T. [Polymorphisms of methylenetetrahydrofolate reductase C677T and the risk of stomach cancer]. Zhonghua Liu Xing Bing Xue Za Zhi 2002;23:289-292.

64. Mu LN, Ding BG, Chen CW, Wei GR, Zhou XF, Wang RH, Cai L, Zhang ZF, Jiang QW, Yu SZ. [A case-control study on the relationship between methyl-tetra-hydrofolic acid reductase 677 gene polymorphism and the risk of stomach cancer]. Zhonghua Liu Xing Bing Xue Za Zhi 2004;25:495-498.

65. Kim JK, Kim S, Han JH, Kim HJ, Chong SY, Hong SP, Hwang SG, Ahn JY, Cha KY, Oh D, Kim NK. Polymorphisms of 5,10-methylenetetrahydrofolate reductase and risk of stomach cancer in a Korean population. Anticancer Res 2005;25:2249-2252.

66. Lacasaña-Navarro M, Galvan-Portillo M, Chen J, Lopez-Cervantes M, Lopez-Carrillo L. Methylenetetrahydrofolate reductase $677 \mathrm{C} / \mathrm{T}$ polymorphism and gastric cancer susceptibility in Mexico. Eur J Cancer 2006;42:528-533.

67. Li D, Ahmed M, Li Y, Jiao L, Chou TH, Wolff RA, Lenzi R, Evans DB, Bondy ML, Pisters PW, Abbruzzese JL, Hassan MM. 5,10-methylenetetrahydrofolate reductase polymorphisms and the risk of pancreatic cancer. Cancer Epidemiol Biomarkers Prev 2005;14: 1470-1476.

68. Wang L, Miao X, Tan W, Lu X, Zhao P, Zhao X, Shan Y, Li H, Lin D. Genetic polymorphisms in methylenetetrahydrofolate reductase and thymidylate synthase and risk of pancreatic cancer. Clin Gastroenterol Hepatol 2005;3:743-751.

69. Matsubayashi H, Skinner HG, lacobuzio-Donahue C, Abe T, Sato $\mathrm{N}$, Riall TS, Yeo CJ, Kern SE, Goggins M. Pancreaticobiliary cancers with deficient methylenetetrahydrofolate reductase genotypes. Clin Gastroenterol Hepatol 2005;3:752-760.

70. Gao CM, Toshiro T, Wu JZ, Cao HX, Liu YT, Ding JH, Li SP, Su P, $\mathrm{Hu}$ X, Kai HT, Kazuo T. [A case-control study on the polymorphisms of methylenetetrahydrofolate reductase $1298 \mathrm{~A} \rightarrow \mathrm{C}$ and susceptibility of esophageal cancer]. Zhonghua Liu Xing Bing Xue Za Zhi 2004;25:341-345.

71. Hillman RS, Steinberg SE. The effects of alcohol on folate metabolism. Annu Rev Med 1982;33:345-354.

72. Stern LL, Mason JB, Selhub J, Choi SW. Genomic DNA hypomethylation, a characteristic of most cancers, is present in peripheral leukocytes of individuals who are homozygous for the C677T polymorphism in the methylenetetrahydrofolate reductase gene. Cancer Epidemiol Biomarkers Prev 2000;9:849-853.

73. Friso S, Choi SW, Girelli D, Mason JB, Dolnikowski GG, Bagley PJ, Olivieri O, Jacques PF, Rosenberg IH, Corrocher R, Selhub J. A common mutation in the 5,10-methylenetetrahydrofolate reductase gene affects genomic DNA methylation through an interaction with folate status. Proc Natl Acad Sci U S A 2002;99:56065611.

74. Dunn BK. Hypomethylation: one side of a larger picture. Ann N Y Acad Sci 2003;983:28-42.

75. Chen RZ, Pettersson U, Beard C, Jackson-Grusby L, Jaenisch R. DNA hypomethylation leads to elevated mutation rates. Nature 1998;395:89-93.

76. Sato N, Maitra A, Fukushima N, van Heek NT, Matsubayashi H, lacobuzio-Donahue CA, Rosty C, Goggins M. Frequent hypomethylation of multiple genes overexpressed in pancreatic ductal adenocarcinoma. Cancer Res 2003;63:4158-4166.

77. Cravo M, Pinto R, Fidalgo P, Chaves P, Gloria L, Nobre-Leitao C, Costa Mira F. Global DNA hypomethylation occurs in the early stages of intestinal type gastric carcinoma. Gut 1996;39: $434-438$. 
78. Cardon LR, Palmer LJ. Population stratification and spurious allelic association. Lancet 2003;361:598-604.

79. Jacobs DR Jr, Marquart L, Slavin J, Kushi LH. Whole-grain intake and cancer: an expanded review and meta-analysis. Nutr Cancer 1998;30:85-96.

80. IARC handbooks of cancer prevention. Fruit and vegetables. In: Vainio H, Bianchini F, eds. Volume 8. Lyon: IARC Press; 2003.

81. Kushi LH, Meyer KA, Jacobs DR Jr. Cereals, legumes, and chronic disease risk reduction: evidence from epidemiologic studies. Am J Clin Nutr 1999;70:451S-458S.

82. Larsson SC, Håkansson N, Näslund I, Bergkvist L, Wolk A. Fruit and vegetable consumption in relation to pancreatic cancer risk: a prospective study. Cancer Epidemiol Biomarkers Prev 2006; 15:301-305.

83. McCullough ML, Robertson AS, Jacobs EJ, Chao A, Calle EE, Thun MJ. A prospective study of diet and stomach cancer mortality in United States men and women. Cancer Epidemiol Biomarkers Prev 2001;10:1201-1205.

84. González CA, Pera G, Agudo A, Bueno-de-Mesquita HB, Ceroti M, Boeing H, Schulz M, Del Giudice G, Plebani M, Carneiro F, Berrino F, Sacerdote C, Tumino R, Panico S, Berglund G, Siman H, Hallmans G, Stenling R, Martinez C, Dorronsoro M, Barricarte A, Navarro C, Quiros JR, Allen N, Key TJ, Bingham S, Day NE, Linseisen J, Nagel G, Overvad K, Jensen MK, Olsen A, Tjonneland A, Buchner FL, Peeters PH, Numans ME, Clavel-Chapelon F, Boutron-Ruault MC, Roukos D, Trichopoulou A, Psaltopoulou T, Lund E, Casagrande C, Slimani N, Jenab M, Riboli E. Fruit and vegetable intake and the risk of stomach and oesophagus adenocarcinoma in the European Prospective Investigation into Cancer and Nutrition (EPIC-EURGAST). Int J Cancer 2006;118:25592566.
85. Stolzenberg-Solomon RZ, Pietinen P, Taylor PR, Virtamo J, Albanes $\mathrm{D}$. Prospective study of diet and pancreatic cancer in male smokers. Am J Epidemiol 2002;155:783-792.

86. Huang JQ, Sridhar S, Chen Y, Hunt RH. Meta-analysis of the relationship between Helicobacter pylori seropositivity and gastric cancer. Gastroenterology 1998;114:1169-1179.

87. Herbert V. Folic acid. In: Shiels M, Olson J, Shike M, Ross AC, eds. Modern nutrition in health and disease. Volume 9. Baltimore, MD: Williams \& Wilkins, 1999:433-446.

88. Giovannucci E, Stampfer MJ, Colditz GA, Rimm EB, Trichopoulos D, Rosner BA, Speizer FE, Willett WC. Folate, methionine, and alcohol intake and risk of colorectal adenoma. J Natl Cancer Inst 1993;85:875-884.

89. Jacques PF, Sulsky SI, Sadowski JA, Phillips JC, Rush D, Willett WC. Comparison of micronutrient intake measured by a dietary questionnaire and biochemical indicators of micronutrient status. Am J Clin Nutr 1993;57:182-189.

90. Bailey LB. Folate and vitamin B12 recommended intakes and status in the United States. Nutr Rev 2004;62:S14-20; discussion S21.

91. Kim YI. Role of folate in colon cancer development and progression. J Nutr 2003;133:3731S-3739S.

Received February 10, 2006. Accepted May 18, 2006.

Address requests for reprints to: Susanna C. Larsson, MSc, Division of Nutritional Epidemiology, National Institute of Environmental Medicine, Karolinska Institutet, Box 210, SE-171 77 Stockholm, Sweden e-mail: susanna.larsson@ki.se; fax: (46) 8-304571.

Supported by the Swedish Research Council/Longitudinal Studies and the Swedish Cancer Foundation. 